\title{
Sitzung vom 13. Juni 1892.
}

Vorsitzender: Hr. H. Landolt.

Das Protokoll der letzten Sitzung wird genehmigt.

Der Vorsitzende begrüsst die in der Sitzung anwesenden auswärtigen Mitglieder Hrn. Dr. Max Koppe aus Höchst a/M. und Hrn. Prof. Nicbolson aus Lincoln.

Der Schriftführer verliest das nachstehende Beileidsschreiben der Chemical Society in London und den unten abgedruckten Auszug aus dem Protokoll der Vorstandssitzung von 25. Mai 1892.

Chemical Society, Burlington House, London. W.

To Prof. Dr. A. Pinner, May $21^{\text {st }} 1892$.

Secretary of the German Chemical Society.

Dear Sir,

I am instructed by the Chemicul Society of London to transmit to you for communication to your Society the following resolution passed at the meeting held on Thursday, May $19^{\text {th }}$ :-

"The President and Council of the Chemical Society, at their first meeting since the death of their illustrious colleague, A ugust Wilhelm von Hofmann, desire to record their sense of his eminence and of the great scientific work he achieved both in England and in Germany.

"Invited to London in 1845 to organise and superintend the Royal College of Chemistry, he spent nearly twenty years in this country and during that time made many brilliant discoveries and trained a body of investigators who have followed bis example in extending the bounds of the science and in applying chemical principles to the industrial arts. Many of the Fellows of the Chemical Society were introduced by him to the Science and look back with gratitude to his inspiring teaching.

"Hofmann's influence on Science in this country still remains, though the country of his birth has, since 1865 , received the immediate benefit of his personal labours as an investigator, teacher, and organiser. 
"The President and Council of the Chemical Society of London desire to express to their colleagues of the German Chemical Society their profound sorrow at the death of the great Chemist so closely connected with both Societies and their sympathy with their sister Society in the loss of their distinguished President."

I am, dear Sir,

$$
\begin{aligned}
& \text { yours obediently, } \\
& \qquad \text { Raphael Meldola, } \\
& \text { Foreign Secretary. }
\end{aligned}
$$

$\mathrm{Zu}$ ausserordentlichen Mitgliedern werden vorgeschlagen die Herren:

Bromberg, Otto, Steglitzerstrasse 23, Berlin W. (durch F. Foerster und F. Mylius);

a m Ende, Friedländerweg 34, Göttingen

Engels, Dr. Paul, Friedländerweg 14, Göttingen,

Jenkins, W. H., Untere Maschstrasse 23, Göttingen, (durch

o. Wallach und

Löb, Walther, Mauerstr. 80, Berlin (durch G. Pulvermacher und E. Rosenthal;

Wechsler, Max, Maria-Theresienstr. 3, Wien IX (durch A. Lieber und H. Jahn);

Jassoy, Dr. A., Löwenapotheke, Frankfurt a/M. (durch E. Schmidt und H. Meyer);

$\mathrm{Sudb}$ or ough, J., Univers.-Laboratorium Heidelberg (durch L. Gattermann und P. Jacobson);

Rivier, Henry, Chem. Laboratorium Neuchâtel (durch A. Hantsch und O. Billeter);

Mault, Karl,

Benack, Julius, Arcisstr. 1$\}$ München (durch W. KöBötzelen, Ernst, ! nigs und E. Buchner); Jäglé, Georg, Türkenstr. 90, I )

Lebbin, Georg, Waldenserstr. 21, I, Berlin NW. (durch F. Tiemann und G. Lemmme)

Levi, Dr. Louis E., 66/72 West Genesee Street, Buffalo N.-Y. (durch J. F. Holtz und R. Daum);

Kaufmann, Victor, Gaisburgstrasse 10, Stuttgart (durch S. Graebe und A. Philips). 